\title{
VOLVER A ASÍN
}

\section{Andrés MARTínEZ LORCA}

En agosto de 1944, en plena madurez intelectual, moría Don Miguel Asín Palacios. Unos meses antes, acababa de preparar la edición y traducción de una obra fundamental de la filosofía hispano-musulmana, El régimen del solitario de Avempace, que aparecería publicada póstumamente en 1946. Y dejo a medio redactar su revolucionario libro Šdilities y alumbrados donde mostraba la influencia de la mística islámica española, de gran arraigo popular a una y otra orilla del Mediterráneo durante los siglos XIII a $X V$, sobre la espiritualidad cristiana de nuestro Siglo de Oro, tanto en su vertiente ortodoxa de los grandes místicos carmelitas, como en la heterodoxa de los «alumbrados» y «dejados».

Hace, pues, algo más de medio siglo que desaparecía este excepcional arabista y hombre de ciencia que a través de sus libros y artículos renovó como pocos la cultura española del siglo XX. Ya en 1919 su maestro Don Julián Ribera destacaba de Asín su honestidad intelectual y una singular tolerancia que le libraba de prevenciones, escrúpulos y fanatismos en sus investigaciones sobre el pensamiento filosófico y teológico del Islam medieval. «Como arabista, es ejemplar único", añadía Ribera. Por su parte, Don Emilio García Gómez, uno de los discípulos predilectos de Asín y su mejor biógrafo, publicó en 1994 un melancólico artículo en su memoria. Denunciaba en él, entre otras cosas, la ignorancia de la obra de Asín entre las nuevas generaciones. «Era el más grande

Endoxa: Series Filosoficas, $n^{\circ} 2,1993$, UNED, Madrid:

Andrés Martinez Lorca: Volver a Asín.

pp. $7-10$ 
arabista español que nunca hubo ni acaso vuelva a haber", sentenciaba Don Emilio a sus noventa años, ya con un pie en el estribo.

A lo largo de su fecunda vida intelectual, y en un total de más de cien trabajos científicos, Miguel Asín prestó especial atención a estos grandes temas: la filosofía de al-Andalus (desde su nacimiento con Ibn Masarra hasta su culminación con Avempace y Averroes, sin olvidar a pensadores de segunda fila como Ibn al-Sid e Ibn Țumlūs); la mística islámica (Ibn al-'Arif, Ibn 'Arabi, Ibn 'Abbåd y la escuela sădili); la teología musulmana (en especial Ibn Hazm cuyo monumental Fișal tradujo y comentó, y Algazel, uno de sus autores preferidos); las relaciones entre el Islam medieval y el mundo cristiano (influencia del monacato cristiano en el sufismo, presencia de la escatología musulmana en la Divina Comedia de Dante, doctrinas filosófico-teológicas de Averroes asimiladas por Tomás de Aquino, e influjo de la escuela sădili en la mística española de los siglos XVI y XVII).

Al final de su vida, en el prólogo a Huellas del Islam, aparecido en 1941, el propio Asín reflexionó sobre el hilo conductor de su trabajo como islamólogo, llegando a la conclusión de que en la historia de la cultura jamás hay solución de continuidad que sea definitiva e irremediable. «Todos mis ensayos tendieron, en efecto, a demostrar los influjos del pensamiento islámico en la cultura cristiana occidental, a la vez que, recíprocamente, el caudal, no menos copioso, de influjos que el Islam recibio de la cultura clásica y cristiana en el Oriente».

El 50 aniversario de la muerte de Don Miguel Asín ha confirmado, una vez más, esa ley del silencio que atenaza desde hace tiempo a la cultura española y que impide con frecuencia el progreso intelectual por simple ignorancia de nuestro pasado. Que yo sepa sólo en su ciudad natal, Zaragoza, celebraron tal aniversario y recordaron su figura, aparte de la Universidad egipcia de El Cairo donde se adelantaron a tal conmemoración con un Congreso científico tan interesante como concurrido al que tuve el honor de asistir. 
Como medievalista que se considera modesto y lejano discípulo de Asín, me he esforzado en los últimos meses por reunir para las páginas de ÉNDOXA un pequeño homenaje al gran arabista aragonés. Ello me parecía más obligado aún dada la calidad e innovación en los estudios de historia de la filosofía que imparte nuestra Facultad. Yo mismo, siguiendo el legado de Asín, he integrado la Filosofía islámica dentro del Programa general de Historia de la Filosofía Medieval, así como la Filosofía hispanomusulmana e hispano-judía dentro del Programa correspondiente de Historia de la Filosofía Española.

El Homenaje a Asín que hoy presentamos a los lectores de ENDOXA es fruto de la generosa colaboración de los siguientes autores: Dolores Oliver, sobrina-nieta de Asín y profesora de Lengua Árabe en la Universidad de Valladolid, que ofrece una original biografía llena valiosas referencias sobre la docencia y la metodología investigadora de Don Miguel; Joaquín Lomba, Catedrático de la Universidad de Zaragoza y Presidente de la Sociedad de Filosofía Medieval, quien analiza de manera casi exhaustiva la presencia de Avempace a lo largo de la producción historiográfica de Asín; Mahmūd 'Alī Makkī, Catedrático de la Universidad de El Cairo y miembro de la Academia Egipcia de la Lengua, galardonado en 1995 con el Premio Nacional de Literatura de Egipto, que nos ofrece una magistral reconstrucción de la cultura religiosa durante el período de esplendor del Califato de Córdoba, a partir de las fuentes históricas árabes; y yo mismo, que he intentado sacar a la luz la primera etapa de la vida intelectual de Asín, es decir, el período de formación y sus primeras publicaciones. Cierra el Homenaje una utilísima Bibliografía de Don Miguel Asín preparada por Joaquín Lomba, de la que sólo se han excluido las reseñas del autor, y a la que complementan los estudios sobre Asín.

Espero que este Homenaje a Don Miguel Asín Palacios contribuya a difundir su pensamiento y su obra entre los jóvenes estudiosos. La cultura española y también la europea necesitan hoy de pioneros como Asín que nos ayuden a innovar, a avanzar sin 
descanso en la senda interminable del conocimiento. Como escribió de él Don Emilio García Gómez, «odiaba repetir lo sabido, manosear el tópico y urdir la síntesis precipitada: sólo le atraían los senderos no hollados». En este confuso fin de siglo, volver a Asín no es, pues, mirar al pasado sino empezar a construir el futuro porque, como lo definió agudamente Luce López-Baralt, Miguel Asín Palacios «es un maestro para el siglo XXI». 